\title{
LONGITUDINAL BONE GROWTH AFTER SCIATIC DENERVATION IN RATS
}

\author{
GERARDO L. GARCÉS, MARÍA E. SANTANDREU
}

From the Colegio Universitario de Las Palmas, Canary Islands

\begin{abstract}
The right sciatic nerve of 50 one-month-old male rats was cut under general anaesthesia. Groups of animals were sacrificed at intervals of up to 12 weeks after operation and the length of the femora, tibiae and first and fifth metatarsals were measured with a caliper accurate to $0.05 \mathrm{~mm}$.

From the first week, both metatarsals were between $3 \%$ and $5 \%$ shorter on the denervated side, but there was no further increase of the discrepancy. The femora were less than $1 \%$ longer in the denervated limb at the second and eighth week. No difference was found between the lengths of the tibiae. The various factors which could possibly be responsible for these findings are discussed.
\end{abstract}

The effect on longitudinal bone growth of dividing peripheral nerves has been studied by a number of authors. Most have reported little change in growth (Allison and Brooks 1921; Armstrong 1946; Gillespie 1954; Landry and Fleisch 1964; Selye and Bajusz 1958; Pennock et al. 1972), but others found decreased growth (Troupp 1961; Kikuchi et al. 1978) and Ring (1961) reported that growth was stimulated. However, most of these workers did not measure bones which were supplied exclusively by the sectioned nerve nor did they present statistical data. All the relevant clinical reports of sciatic nerve injury in childhood indicate that this produces decreased growth of the foot (Combes et al. 1960; Curtiss and Tucker 1960; Gilles and French 1961; Seligra et al. 1978; Esteban and Diaz 1981). We have investigated the effect of division of the sciatic nerve on longitudinal bone growth in rats.

\section{MATERIAL AND METHODS}

A total of 50 Sprague-Dawley male rats aged 30 days and weighing approximately $90 \mathrm{~g}$ were used. Under chloral hydrate anaesthesia, through a longitudinal incision in the right buttock, the sciatic nerve was cut at the sciatic notch, $1.5 \mathrm{~cm}$ excised from the distal end and the skin

G. L. Garcés, LMS, DM, Assistant Professor
M. E. Santandreu, LMS, DM, Research Fellow

Orthopaedic Research Unit, Department of Anatomy, Colegio Universitario, Aptdo 550, Las Palmas de Gran Canarias, Canary Islands, Spain.

Requests for reprints should be sent to Dr G. L. Garcés.

(C) 1988 British Editorial Society of Bone and Joint Surgery 0301-620X/88/2063 $\$ 2.00$

J Bone Joint Surg [Br] 1988 ;70-B: 315-8. closed. The animals were kept in standard conditions with free supplies of food and water.

There were five groups, each of 10 rats, which were killed at 1, 2, 4, 8 and 12 weeks after operation. The femora, tibiae and first and fifth metatarsals were separated from the soft tissues of both hind limbs, using a microscope for the small bones. The length of each bone was then measured by three different investigators each using a caliper accurate to $0.05 \mathrm{~mm}$. Femoral measurements were made from the tip of the femoral head to the tip of the medial condyle, and tibial length was measured from the most proximal part of the condyles to the tip of the medial malleolus. The total length of the metatarsals was recorded. The resulting data were processed in a HP3000 computer with an SPSS program, using a twotailed $t$-test for paired samples.

\section{RESULTS}

There was no evidence of functional recovery of sciatic nerves and no animal became infected or died prematurely. A few nerves appeared to be in continuity by the eighth week, but histological study showed a neuroma at the level of the sciatic notch and fibrous tissue distally. There was progressive loss of muscle bulk in the posterior thigh and calf, while the anterior thigh maintained its muscle bulk.

The measurements are shown in Tables I to IV. There were no significant differences in length of the tibiae. On the denervated side, the femora were less than $1 \%$ longer than on the control side during the whole study, but this difference was significant only at the second and twelfth week. The first and fifth metatarsals in the denervated limb were respectively $4 \%$ and $3 \%$ shorter than those in the control limbs at the first week; 
these differences were maintained at between $3 \%$ and $5 \%$ during follow-up, and were highly significant.

\section{DISCUSSION}

Reports on longitudinal bone growth in limbs after sciatic denervation have concluded that the peripheral nervous system has no effect on bone length (Gillespie 1954; Selye and Bajusz 1958; Pennock et al. 1972). However, in all these experiments only femora and tibiae have been measured, bones whose length may be affected by the influence of, for example, the femoral and obturator nerves. Other reports give different results. Troupp (1961) found in rabbits that the more motor roots of the lumbar spine that were cut the greater was the diminution of femoral growth and, to a lesser extent, tibial growth. These results can be questioned because only one animal was assessed at each time interval. Ring (1961) found an increase in the size of tibiae after motor denervation in puppies, but only six of 40 animals showed $3 \%$ or more of overgrowth.

We used a reliable method to remove permanently the influence of the sciatic nerve on the hind limb. Muscle wasting and, more importantly, histological examination gave proof of denervation. Measurements were taken by three different observers to ensure accuracy; although pressure on the articular cartilage by the caliper could alter the results, our low inter-observer error confirms the reproducibility of the method.

We showed that the femora on the denervated side were always slightly longer than those on the control side. This agrees with the findings of Pennock et al. (1972) four weeks after sciatic denervation. However, Gillespie (1954) found discrepancy in femoral length in these circumstances though he did not publish detailed results or statistical data.

In our animals tibial length was not affected by denervation; this was also found by Selye and Basjuz (1958) and by Gillespie (1954), though Ring (1961), who measured only diaphyseal length, observed a slight increase in length on the denervated side.

We measured metatarsals because they are innervated exclusively by the sciatic nerve, and showed that on the denervated side they grew about $3 \%$ to $5 \%$ less than on the control side. This was so from the first week, the difference being maintained throughout the study period. Santandreu (1986) has shown that in metatarsals the height of the growth plate was reduced one week after sciatic denervation but that this became normal by the second week. These growth plates close between 8 and 12 weeks, so no differences in length should be expected after 12 weeks. Her findings suggest that changes are produced very early after denervation; the lack of nerve influence becomes less important for the remainder of the growth period. Curtiss and Tucker (1960) studied 10 premature children with transient sciatic nerve palsy following injections, who had all gained functional recovery after four months. Three years later, the ipsilateral foot was one to two centimetres shorter than the other foot in nine of the 10 children. We have been unable to find any references to other experimental work on metatarsal length and sciatic denervation.

Most authors consider that the peripheral nervous system has no direct effect on bone growth, but that it could act through other factors. Immobilisation after nerve section has been claimed to be responsible (Allison

Table I. Change in femoral length after right-sided sciatic denervation in five groups of 10 rats

\begin{tabular}{|c|c|c|c|c|c|}
\hline \multirow{2}{*}{$\begin{array}{l}\text { Weeks after } \\
\text { denervation }\end{array}$} & \multirow[b]{2}{*}{ Side } & \multicolumn{2}{|c|}{ Length (mm) } & \multirow{2}{*}{$\begin{array}{l}\text { Confidence } \\
\text { interval* }\end{array}$} & \multirow{2}{*}{$\begin{array}{l}\text { p value o } \\
\text { difference }\end{array}$} \\
\hline & & $\overline{\text { Mean }}$ & s.d. & & \\
\hline 1 & $\begin{array}{l}\text { Right } \\
\text { Left }\end{array}$ & $\begin{array}{l}25.02 \\
24.93\end{array}$ & $\begin{array}{l}0.83 \\
0.82\end{array}$ & $0.09 \pm 0.15$ & NS \\
\hline 2 & $\begin{array}{l}\text { Right } \\
\text { Left }\end{array}$ & $\begin{array}{l}26.73 \\
26.60\end{array}$ & $\begin{array}{l}1.46 \\
1.36\end{array}$ & $0.13 \pm 0.07$ & 0.002 \\
\hline 4 & $\begin{array}{l}\text { Right } \\
\text { Left }\end{array}$ & $\begin{array}{l}31.54 \\
31.52\end{array}$ & $\begin{array}{l}2.37 \\
2.36\end{array}$ & $0.02 \pm 0.25$ & NS \\
\hline 8 & $\begin{array}{l}\text { Right } \\
\text { Left }\end{array}$ & $\begin{array}{l}36.65 \\
36.63\end{array}$ & $\begin{array}{l}1.36 \\
1.41\end{array}$ & $0.02 \pm 0.17$ & NS \\
\hline 12 & $\begin{array}{l}\text { Right } \\
\text { Left }\end{array}$ & $\begin{array}{l}38.27 \\
38.02\end{array}$ & $\begin{array}{l}0.98 \\
1.14\end{array}$ & $0.25 \pm 0.16$ & 0.008 \\
\hline
\end{tabular}

* $95 \%$ confidence interval as calculated for paired samples

Table II. Changes in tibial length after right-sided sciatic denervation in five groups of 10 rats

\begin{tabular}{|c|c|c|c|c|c|}
\hline \multirow{2}{*}{$\begin{array}{l}\text { Weeks after } \\
\text { denervation }\end{array}$} & \multirow[b]{2}{*}{ Side } & \multicolumn{2}{|c|}{ Length (mm) } & \multirow{2}{*}{$\begin{array}{l}\text { Confidence } \\
\text { interval* }\end{array}$} & \multirow{2}{*}{$\begin{array}{l}\text { p value o } \\
\text { difference }\end{array}$} \\
\hline & & Mean & s.d. & & \\
\hline 1 & $\begin{array}{l}\text { Right } \\
\text { Left }\end{array}$ & $\begin{array}{l}29.41 \\
29.50\end{array}$ & $\begin{array}{l}0.68 \\
0.75\end{array}$ & $0.09 \pm 0.14$ & NS \\
\hline 2 & $\begin{array}{l}\text { Right } \\
\text { Left }\end{array}$ & $\begin{array}{l}30.84 \\
30.88\end{array}$ & $\begin{array}{l}1.43 \\
1.56\end{array}$ & $0.04 \pm 0.07$ & NS \\
\hline 4 & $\begin{array}{l}\text { Right } \\
\text { Left }\end{array}$ & $\begin{array}{l}36.06 \\
36.24\end{array}$ & $\begin{array}{l}1.91 \\
2.09\end{array}$ & $0.18 \pm 0.24$ & NS \\
\hline 8 & $\begin{array}{l}\text { Right } \\
\text { Left }\end{array}$ & $\begin{array}{l}40.49 \\
40.61\end{array}$ & $\begin{array}{l}1.36 \\
1.41\end{array}$ & $0.12 \pm 0.21$ & NS \\
\hline 12 & $\begin{array}{l}\text { Right } \\
\text { Left }\end{array}$ & $\begin{array}{l}41.71 \\
41.86\end{array}$ & $\begin{array}{l}1.13 \\
1.11\end{array}$ & $0.15 \pm 0.22$ & NS \\
\hline
\end{tabular}

* $95 \%$ confidence interval as calculated for paired samples

and Brooks 1921; Gillespie 1954; Landry and Fleisch 1961 ; Troupp 1961; Pennock et al. 1972). Poliomyelitis is the main clinical source for this hypothesis, but the immediate effect of the neuronal lesion in this disease is to produce lengthening of the bones of the affected limb. This lengthening happens during the first year and may persist during the second year in spite of the muscle palsy (Ring 1961). 
Garcés (1986) showed that, after four weeks of immobilisation in plaster, the tibiae of rats progressively increased by up to $3 \%$ in length when compared with the control side $(p<0.001)$. Garcés and Ramirez (1987) observed that the growth plates in immobilised tibiae showed no alterations in their micro-anatomy, but that, after four weeks, the synthesis of proteoglycans was relatively increased in the immobilised growth plates when measured by alcian blue staining. If the effect of

Table III. Changes in length of the first metatarsal after right-sided sciatic denervation in five groups of 10 rats

\begin{tabular}{|c|c|c|c|c|c|}
\hline \multirow{2}{*}{$\begin{array}{l}\text { Weeks after } \\
\text { denervation }\end{array}$} & \multirow[b]{2}{*}{ Side } & \multicolumn{2}{|c|}{ Length ( $\mathrm{mm}$ ) } & \multirow{2}{*}{$\begin{array}{l}\text { Confidence } \\
\text { interval* }\end{array}$} & \multirow{2}{*}{$\begin{array}{l}\text { P value of } \\
\text { difference }\end{array}$} \\
\hline & & Mean & s.d. & & \\
\hline 1 & $\begin{array}{l}\text { Right } \\
\text { Left }\end{array}$ & $\begin{array}{l}7.21 \\
7.46\end{array}$ & $\begin{array}{l}0.22 \\
0.35\end{array}$ & $0.25 \pm 0.16$ & 0.006 \\
\hline 2 & $\begin{array}{l}\text { Right } \\
\text { Left }\end{array}$ & $\begin{array}{l}7.55 \\
7.83\end{array}$ & $\begin{array}{l}0.39 \\
0.51\end{array}$ & $0.28 \pm 0.14$ & 0.001 \\
\hline 4 & $\begin{array}{l}\text { Right } \\
\text { Left }\end{array}$ & $\begin{array}{l}8.64 \\
9.03\end{array}$ & $\begin{array}{l}0.61 \\
0.60\end{array}$ & $0.39 \pm 0.12$ & $<0.001$ \\
\hline 8 & $\begin{array}{l}\text { Right } \\
\text { Left }\end{array}$ & $\begin{array}{l}9.23 \\
9.43\end{array}$ & $\begin{array}{l}0.21 \\
0.15\end{array}$ & $0.20 \pm 0.08$ & $<0.001$ \\
\hline 12 & $\begin{array}{l}\text { Right } \\
\text { Left }\end{array}$ & $\begin{array}{l}9.23 \\
9.45\end{array}$ & $\begin{array}{l}0.26 \\
0.26\end{array}$ & $0.22 \pm 0.07$ & $<0.001$ \\
\hline
\end{tabular}

* $95 \%$ confidence interval as calculated for paired samples

Table IV. Changes in length of the fifth metatarsal bone after rightsided denervation in five groups of 10 rats

\begin{tabular}{llllll}
\hline $\begin{array}{l}\text { Weeks after } \\
\text { denervation }\end{array}$ & Side & Mean & s.d. & $\begin{array}{l}\text { Length }(\mathbf{m m}) \\
\text { Conterval }{ }^{*}\end{array}$ & $\begin{array}{l}\text { p value of } \\
\text { difference }\end{array}$ \\
\hline 1 & $\begin{array}{l}\text { Right } \\
\text { Left }\end{array}$ & 12.01 & 0.25 & & \\
& 12.36 & 0.29 & $0.35 \pm 0.13$ & $<0.001$ \\
2 & $\begin{array}{l}\text { Right } \\
\text { Left }\end{array}$ & 12.21 & 0.49 & & \\
& 12.68 & 0.61 & $0.47 \pm 0.12$ & $<0.001$ \\
4 & $\begin{array}{l}\text { Right } \\
\text { Left }\end{array}$ & 13.35 & 0.75 & & \\
8 & 13.99 & 0.67 & $0.64 \pm 0.10$ & $<0.001$ \\
& Right & 13.66 & 0.36 & & \\
12 & Left & 14.23 & 0.44 & $0.57 \pm 0.10$ & $<0.001$ \\
& Right & 13.61 & 0.35 & & \\
\hline
\end{tabular}

* $95 \%$ confidence interval as calculated for paired samples

the nerve section on longitudinal bone growth were mediated through immobilisation and lost muscle function, then one would expect a progressive increase in the discrepancy after denervation. It therefore seems unlikely that these factors could explain our findings.

Another explanation for metatarsal shortening could be alterations in blood supply after denervation. Ferguson and Akahoshi (1960) showed increased vascu- larity around the ankle and knee at three and six weeks after sciatic denervation without alteration of the main vascular pattern. Shim, Copp and Patterson (1966) showed an increase of more than $45 \%$ in blood flow to the foot at 8 and 15 days after sciatic denervation in rabbits. Since an increased blood supply stimulates longitudinal bone growth (Goetz, Du Toit and Swart 1955), this factor could not explain our findings.

The absence of weight-bearing may modify longitudinal bone growth. Simon (1978) suggested that, within certain limits, both the relief of and increase in dynamic loading could accelerate epiphyseal growth. According to this hypothesis, as the whole denervated limb is unloaded, one would expect all the bones to be similarly affected. This did not happen. The increase in relative length of the femora could be explained by decreased growth on the control side because of overloading. In fact, the femora of matched rats were found to be slightly longer than the control femora from the present study (Garcés 1986; Santandreu 1986). However, the significant differences were so small $(0.12 \mathrm{~mm}$ at the second week, $0.15 \mathrm{~mm}$ at the twelfth week) that these results could be due to experimental error. Tibial length was not affected by sciatic denervation, so lack of weight-bearing did not influence tibial growth.

The peripheral nervous system does not seem to exert a major influence on longitudinal bone growth. The early reduction of metatarsal length in the denervated limb with no further increase in the discrepancy suggests that when a limb is denervated bone growth stops or slows down for a while and then continues normally. Our results and those of Curtiss and Tucker (1960) suggest that the initial growth retardation will never undergo compensation. Biochemical investigations may help to elucidate the mechanisms involved in this retardation. We thank Mr M. K. Benson for his help in the preparation of the
manuscript and Mr J. Wilson-MacDonald for his help in the
translation.

\section{REFERENCES}

Allison N, Brooks B. Bone atrophy, an experimental and clinical study of the changes in bone which result from non-use. Surg Gynecol Obstet 1921;33:250.

Armstrong WD. Bone growth in paralyzed limbs. Proc Soc Exp Biol Med 1946:61:358-62.

Combes MA, Clark WK, Gregory CF, James JA. Sciatic nerve injury in infants: recognition and prevention of impairment resulting from intragluteal injections. $J A M A$ 1960;173:1336-9.

Curtiss PH Jr, Tucker HJ. Sciatic palsy in premature infants: a report and follow-up study of ten cases. JAMA 1960;174:1586-8.

Esteban B, Diaz J. Lesiones del nervio ciatico postinyeccion glutea. I. Estudio clinico. Rev Orthop Traum 1981;25:67-80. (Eng. Abstr.)

Ferguson AE Jr, Akahoshi Y. Vascular patterns in immobilized, denervated or devascularized rabbit limbs. J Bone Joint Surg [Am] $1960 ; 42-A: 617-24$. 
Garces G. Crecimiento femorotibial en miembros inmovilizados de rata. Rev Esp de Cir Ost 1986;21:105-8. (Eng. Abstr.)

Garces G, Ramirez JA. Efectos de la inmovilización en posición funcional sobre los cartilagos de crecimiento tibiales: estudio histológico e histoquímico. Rev Orthop Traum 1987;31:103-7. (Eng. Ábstr.)

Gilles FH, French JH. Postinjection sciatic nerve palsies in infants and children. J Pediatr 1961;58:195-204.

Gillespie JA. The nature of the bone changes associated with nerve injuries and disuse. J Bone Joint Surg [Br] 1954;36-B:464-73.

Goetz RH, Du Toit JG, Swart BH. Vascular changes in poliomyelitis and the effect of sympathectomy on bone growth. Acta Med Scand 1955; Suppl 306.

Kikuchi M, Lu C-H, Sebata M, Yamamoto Y. The mandibular development of the rat after the denervation of the masseteric nerve. Bull Tokyo Dent Coll 1978;19:78-86.

Landry $\mathbf{M}$, Fleisch $\mathbf{H}$. The influence of immobilisation on bone formation as evaluated by osseous incorporation of tetracyclines. $J$ Bone Joint Surg [Br] 1964;46-B:764-71.
Pennock JM, Kalu DN, Clark MB, Foster GV, Doyle FH. Hypoplasia of bone induced by immobilization. $B r J$ Radiol 1972;45: $641-6$.

Ring PA. The influence of the nervous system upon the growth of bones. J Bone Joint Surg [Br] $1961 ; 43-B: 121-40$.

Santandreu M. Efectos de la denervación ciática sobre los cartilagos de crecimiento. Doctoral Thesis, Zaragoza, 1986.

Seligra A, Escudero M, Delagdo M, Garcia M. Revisión y estudio de las secuelas en pacientes con antiguas lesiones ciáticas postinyección. Rev Esp de Cir Ost 1978;13:161-8. (Eng. Abstr.)

Selye H, Bajusz E. Effect of denervation on experimentally induced changes in the growth of bone and muscle. Am J Physiol $1958 ; 192: 297-300$.

Shim SS, Copp DH, Patterson FP. Bone blood flow in the limb following complete sciatic nerve section. Surg Gynecol Obstet $1966 ; 123: 333-5$.

Simon MR. The effect of dynamic loading on the growth of epiphyseal cartilage in the rat. Acta Anat [Basel] 1978; 102:176-83.

Troupp H. Nervous and vascular influence on longitudinal growth of bone: an experimental study on rabbits. Acta Orthop Scand $1961 ;$ Suppl 51. 